\title{
Lung Chitinolytic Activity and Chitotriosidase Are Elevated in Chronic Obstructive Pulmonary Disease and Contribute to Lung Inflammation
}

\author{
Séverine Létuvé, ${ }^{\star \dagger}$ Alexander Kozhich, ${ }^{\ddagger}$ \\ Alison Humbles, ${ }^{\ddagger}$ Yambasu Brewah, ${ }^{\ddagger}$ \\ Marie-Christine Dombret, ${ }^{* \dagger} \llbracket$ \\ Martine Grandsaigne,${ }^{* \dagger}$ Homa Adle," \\ Roland Kolbeck, ${ }^{\ddagger}$ Michel Aubier, ${ }^{* \uparrow \S \pi}$ \\ Anthony J. Coyle, ${ }^{\ddagger}$ and Marina Pretolani* ${ }^{\star \dagger T}$ \\ From the Institut National de la Santé et de la Recherche \\ Médicale (Inserm) U700, Paris, France; the Université Paris $7,{ }^{\dagger}$ \\ Faculté de Médecine Denis Diderot, Site Bichat, Paris, France; \\ the Department of Autoimmunity, Inflammation and Respiratory

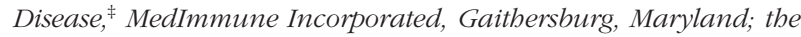 \\ Département de Pneumologie $A,{ }^{\S}$ Centre Hospitalier Universitaire \\ Bichat-Claude Bernard, Paris, France; and Assistance Publique \\ des Hôpitaux de Paris, ${ }^{\top}$ Paris, France; the Département \\ d'Anatomie et Cytologie Pathologiques," Centre Hospitalier \\ Universitaire Bichat-Claude Bernard, Paris, France
}

Chronic obstructive pulmonary disease (COPD) is characterized by chronic airway inflammation and emphysematous alveolar destruction. In this study, we have investigated whether chitotriosidase (ChTRase) and acidic mammalian chitinase, two chitinases with chitinolytic activity, are selectively augmented in COPD and contribute to its pathogenesis. We found that smokers with COPD, but not asthmatics, had higher chitinolytic activity and increased levels of ChTRase in bronchoalveolar lavage, more ChTRasepositive cells in bronchial biopsies, and an elevated proportion of alveolar macrophages expressing ChTRase than smokers without COPD or never-smokers. ChTRase accounted for approximately $80 \%$ of bronchoalveolar lavage chitinolytic activity, while acidic mammalian chitinase was undetectable. Bronchoalveolar lavage chitinolytic activity and ChTRase were associated with airflow obstruction and emphysema and with the levels of interleukin (IL)-1 $\beta$, IL-8, tumor-necrosis factor (TNF)- $\alpha$, and its type II soluble receptor. Tumor necrosis factor- $\alpha$ stimulated ChTRase release only from alveolar macrophages from smokers with COPD, and exposure of these cells to ChTRase promoted the release of $\mathrm{IL}-8$, monocyte-chemoattractant protein-1, and metalloproteinase-9. Finally, ChTRase overexpression in the lung of normal mice promoted macrophage recruitment and the synthesis of the murine homologue of IL-8, keratinocyte-derived cytokine, and of monocyte-chemoattractant protein-1. We conclude that pulmonary ChTRase overexpression may represent a novel important mechanism involved in COPD onset and progression. ( $A m$ J Pathol 2010, 176:638-649; DOI: 10.2353/ajpath.2010.090455)

Chronic obstructive pulmonary disease (COPD), a debilitating respiratory condition, is a significant cause of morbidity, mortality, and health care costs worldwide and its global burden is increasing. ${ }^{1}$ The defining feature of COPD is irreversible airflow limitation measured during forced expiration, caused by either an increase in airway resistance, or in lung compliance due to emphysematous lung destruction, or both. ${ }^{1} \mathrm{~A}$ dominant hallmark of COPD is an abnormal inflammatory response to inhaled particles and this has the potential to produce lung injury. ${ }^{1-3}$ Recent data suggest that emphysema results from an exaggerated synthesis, predominantly by neutrophils and macrophages, of serine and cysteine proteases and matrix-degrading metalloproteinases (MMPs), enzymes that promote cell activation and injury and that degrade connective tissue components. ${ }^{3-5}$

Recently, a family of enzymes named chitinases has been identified in humans and rodents. ${ }^{6}$ These enzymes are endo- $\beta-1,4-N$-acetylglucosamidases that degrade chitin, an abundant wall- and exoskeleton-derived polysaccharide that protects nematodes, fungal cells, and insects from the animal and plant hosts that they in-

Supported in part by the "Fondation pour la Recherche Médicale" (fellowship to S.L.) and by a grant from Medimmune Incorporated.

S.L. and A.K. contributed equally to this study.

Accepted for publication October 6, 2009.

Supplemental material for this article can be found on http://ajp. amjpathol.org

Address reprint requests to Marina Pretolani, Ph.D., Inserm U700, Université Paris 7, Faculté de Médecine Denis Diderot, Site Bichat -16, rue Henri Huchard, 75018 Paris, France. E-mail: marina.pretolani@inserm.fr. 
vade. $^{7,8}$ Although chitin does not have a mammalian counterpart, elevated chitinolytic activity and prominent expression of the two chitinases that catalyze the hydrolysis of chitin, namely chitotriosidase (ChTRase) and acidic mammalian chitinase (AMCase), have been associated with pathological conditions that are characterized by tissue inflammation and remodeling, including atherosclerosis and asthma. ${ }^{9-11}$

In the present study, we investigated whether chitinoIytic activity and the expression of ChTRase and AMCase are augmented in the airways of patients with COPD and whether they contribute to inflammatory and remodeling responses by activating alveolar macrophages, an important orchestrator of these responses. ${ }^{5}$ We found that chitinolytic activity was elevated in the airways of patients with COPD, and that the majority of this activity was accountable by ChTRase, but not AMCase. Moreover, ChTRase activated the synthesis of pro-inflammatory and remodeling chemokines and metalloproteinases by alveolar macrophages and its overexpression in the airways of normal mice induced macrophage recruitment and up-regulated the levels of pro-inflammatory and fibrogenic chemokines that have been implicated in the pathogenesis of COPD. Taken together, these findings demonstrate that COPD is characterized by elevated levels of ChTRase and suggest that this chitinase contributes to disease pathogenesis and progression.

\section{Materials and Methods}

\section{Subjects and Sample Collection}

Twenty current heavy smokers without COPD, and 30 smokers (17 current and 13 former) with stable COPD were recruited (Supplementary Table S1, at http://ajp. amjpathol.org). COPD severity was graded into stages II ( $n=22)$, III $(n=4)$, and IV $(n=4)$, following the Guidelines of the Global Initiative for Obstructive Lung Disease. ${ }^{12}$ Two out of the 30 patients with COPD were treated with $\leq 1000 \mu \mathrm{g} /$ day of equivalent beclomethasone, and no maintenance therapy, other than bronchodilators, was required. Heavy smokers without COPD had chronic cough and sputum but normal measurements on spirometry. In parallel, 40 never-smoker asthmatic subjects, mainly atopics and fulfilling the criteria of the Guidelines for the Diagnosis and Management of Asthma of the National Heart, Lung, and Blood Institute/World Health Organization ${ }^{13}$ were recruited (Supplementary Table S2, at http://ajp.amjpathol.org). None of the subjects had experienced asthma exacerbation within the 2 months preceding the bronchoscopy. The 40 asthmatic subjects were distributed into mild $(n=15)$, moderate $(n=10)$, and severe $(n=15)$ asthmatics (Supplementary Table S2, at http://ajp.amjpathol.org). ${ }^{13}$ Mild and moderate asthmatics had normal baseline lung function (prebronchodilator forced expiratory volume in 1 second $\geq 80 \%$ and forced expiratory volume in 1 second/forced vital capacity $\geq 70 \%$ of predicted values). Mild asthmatics were treated exclusively with inhaled short-acting $\beta 2$ agonists, taken as needed, whereas moderate asthmat- ics received 250 to $1000 \mu \mathrm{g}$ per day of fluticasone propionate, or equivalent, in association with short $(n=$ $10)$ or long- ( $n=5)$ acting $\beta 2$-agonists to achieve control (Supplementary Table S2, at http://ajp.amjpathol.org). Severe asthmatics were defined on the basis of the requirement of high-dose inhaled steroids ( $>1000 \mu \mathrm{g}$ of fluticasone propionate or equivalent per day) and a longlasting $\beta 2$-agonist, as add-on therapy to achieve control. ${ }^{13}$ Four out of the 15 severe asthmatics were also treated with 10 to $40 \mathrm{mg}$ per day of oral prednisone (Supplementary Table S2, at http://ajp.amjpathol.org).

A group of 20 never-smoker healthy volunteers, not receiving any medication, was also studied. All of them had normal respiratory function, no bronchodilator response, no chronic illness, no history of allergy or asthma and their skin prick tests were negative. The protocol was approved by the Hôtel Dieu hospital Ethics Committee (CP 02819) and all subjects gave their written informed consent before being enrolled in the study.

Bronchoalveolar lavage (BAL) was collected by bronchoscopy $^{14,15}$ and stored as cell-free supernatant at $-80^{\circ} \mathrm{C}$ until use. Cytospin preparations from BAL cells were fixed in 4\% paraformaldehyde and stored dried at $-20^{\circ} \mathrm{C}$ until use. Two biopsies were taken from the subcarinae in 10 representative never-smokers and in smokers with and without COPD ( $n=12$ in each group). In addition, lung tissue specimens were collected at distance of the tumor in two never-smokers, three smokers, and four patients with COPD who underwent lung lobectomy for peripheral lung carcinoma. All tissue samples were fixed immediately in 3.7\% formaldehyde and embedded in paraffin wax. ${ }^{14}$

\section{Generation of Proteins and Antibodies}

The 293-F cell line was transfected using 293 fectin with PCDNA 3.1 plasmids (all from Invitrogen, Carlsbad, CA) encoding human ChTRase (NM_003465), or AMCase (NM_021797). To facilitate purification, a His Tag (the sequence of six histidine residues) was expressed at C-terminus of the proteins. Recombinant proteins were purified from cell supernatants using Ni columns and were characterized by Western blot and chitinolytic activity assay, as described below, as well as using SDS-polyacrylamide gel electrophoresis, size exclusion chromatography-high-performance liquid chromatography, and mass spectrometry. Preparations were sterilized by passage through $0.2-\mu \mathrm{m}$ filters and endotoxin content was below $3 \mathrm{EU} / \mathrm{mg}$ of protein (Lymulus Amoebocyte Lysate assay, Associates of Cape Cod, East Falmouth, MA).

Polyclonal sera were generated by immunizing rabbits (Covance, Denver, CO) with purified recombinant ChTRase or AMCase in complete Freund's adjuvant. The IgGs were subsequently purified using protein G columns (GE Health care, Piscataway, NJ). The specificity and titers of the sera and of the purified anti-ChTRase and anti-AMCase IgGs were determined by an enzymelinked immunosorbent assay (ELISA) developed in house and by Western blot analysis, as described below. 


\section{Development and Validation of ChTRase and AMCase ELISA}

Nunc Maxisorp plates (VWR, West Chester, PA) were coated with rabbit anti-human ChTRase polyclonal IgG \#657 (500 ng/ml in PBS, $100 \mu \mathrm{l} / \mathrm{well}$ ) overnight at $2^{\circ} \mathrm{C}$ to $8^{\circ} \mathrm{C}$. Plates were then blocked for 1 hour at room temperature with assay buffer (0.1\% Tween 20 in PBS, T-PBS) containing $0.5 \%$ casein. After extensive wash, standards ( 0.001 to $1000 \mathrm{ng} / \mathrm{ml}$ ), or samples were added for 1 hour at room temperature. After wash, biotinylated anti-human ChTRase Ab \#657 (500 ng/ml) was added for 1 hour, followed by incubation for 1 hour with 1:25,000 dilution of streptavidin-horseradish peroxidase conjugate (GE Health care) in assay buffer. 3,3',5,5'-Tetramethylbenzidine (KPL, Gaithersburg, MD) was used as a substrate, and reaction was stopped after 10 minutes by adding $0.2 \mathrm{~mol} / \mathrm{L} \mathrm{H}_{2} \mathrm{SO}_{4}$. Optical densities were read at $450 \mathrm{~nm}$ using a Spectramax M5 microplate reader (Molecular Devices, Sunnyvale, CA). Assay sensitivity was $100 \mathrm{pg} / \mathrm{ml}$ human ChTRase.

The same protocol as described above was used for developing AMCase ELISA, except that monoclonal mouse anti-human AMCase Ab \#107 $(1 \mathrm{mg} / \mathrm{ml}$ in bicarbonate buffer, $100 \mu \mathrm{l} / \mathrm{well}$ ) was used for capture and biotinylated rabbit anti-human AMCase Ab \#655 (500 $\mathrm{ng} / \mathrm{ml}$ in PBS) was used for detection. Streptavidin-horseradish peroxidase conjugate was used at 1:50,000 dilution in assay buffer. Assay sensitivity was $4 \mathrm{ng} / \mathrm{ml}$ human AMCase. Absence of cross-reactivity with AMCase for ChTRase ELISA, and with ChTRase, for AMCase ELISA, was confirmed using concentrations of the purified proteins up to $100 \mathrm{ng} / \mathrm{ml}$ (Supplementary Figure S1A, at http://ajp.amjpathol.org).

\section{Validation of the Specificity of the Abs by Western Blot}

Purified ChTRase or AMCase (10, 25, and $50 \mathrm{ng} / \mathrm{ml}$ ) were separated on a $10 \%$ SDS- polyacrylamide gel electrophoresis and transferred onto polyvinyldifluoride membranes. Membranes were blocked for 1 hour in T-PBS and $5 \%$ nonfat milk, and incubated for 1 hour with $1 \mu \mathrm{g} / \mathrm{ml}$ rabbit anti-human ChTRase \#657 Ab or rabbit anti-human AMCase \#655 Ab in T-PBS. After three washes in T-PBS, membranes were incubated with a 1:4000 dilution of horseradish peroxidase-conjugated goat anti-rabbit $\mathrm{Ab}$ (GE Health care), in T-PBS. After extensive washing in T-PBS, immunoblots were developed with enhanced chemiluminescence reagent (GE Health care) (Supplementary Figure S1B, at http://ajp.amjpathol.org). Protein deposition was confirmed by staining the membranes with silver nitrate (Sigma) (data not shown). Specificity of the Abs was also assessed using protein extracts from alveolar macrophages from two smokers with and without COPD (Supplementary Figure S1C, at http://ajp. amjpathol.org). Proteins $(20 \mu \mathrm{g})$ were separated on a $10 \%$ SDS-polyacrylamide gel electrophoresis and membranes were reacted for 1 hour with $1 \mu \mathrm{g} / \mathrm{ml}$ rabbit antihuman ChTRase \#657 before chemiluminescent visualization, as described above.

\section{Immunohistochemistry and Immunofluorescence}

Serial $5-\mu m$ sections from acetone-fixed, frozen bronchial biopsies and cytospin preparations of BAL cells were subsequently incubated with $2 \mu \mathrm{g} / \mathrm{ml}$ of rabbit polyclonal Abs directed against human ChTRase or AMCase (\# 657 and \# 655, respectively), biotin-conjugated anti-rabbit Ab and avidin-biotinylated alkaline phosphatase complex from the Vectastain kit (Vector, Burlingame, CA). Reaction was developed using Fast Red (DakoCytomation, Trappes, France), used as a substrate and nuclei were visualized with light Mayer's hematoxylin counterstaining. ${ }^{14-16}$ Negative controls included control rabbit IgG (DakoCytomation) instead of the primary $\mathrm{Ab}$, or primary Abs adsorbed with purified ChTRase or AMCase. Positive cells in bronchial biopsy sections were expressed as numbers of cells $/ \mathrm{mm}^{2}$ total biopsy areas. ${ }^{14,16}$ ChTRasepositive alveolar macrophages were enumerated in cytospin preparations from BAL after counting at least 200 cells in randomly selected fields. ${ }^{14}$

Paraffin-embedded lung tissue specimens were subjected to heat-induced antigen retrieval in citrate buffer and reacted with $4 \mu \mathrm{g} / \mathrm{ml}$ of the anti-ChTRase, or the anti-AMCase $\mathrm{Ab}$ and binding was visualized using Fast Red as described above, or biotin-conjugated anti-rabbit Ab followed by AlexaFluor 568-conjugated streptavidin (Invitrogen). The localization of ChTRase within alveolar macrophages (in bronchial biopsies and lung specimens), and neutrophils (in bronchial biopsies exclusively) was examined by immunofluorescent double staining using a mouse anti-human CD68 monoclonal Ab (clone PG-M1, 1:50 dilution, DakoCytomation), or a mouse antihuman neutrophil elastase monoclonal Ab (clone NP57, 1:50 dilution, DakoCytomation), or their control isotypes, mouse $\lg \mathrm{G} 3 \kappa$ and mouse $\operatorname{lgG} 1 \kappa$, respectively. This was followed by goat anti-mouse AlexaFluor 488 (Molecular Probes), treatment with RNase and incubation with TO-PRO-3 (Molecular Probes) to stain nuclei. Slides were examined using a Plan Apochromat $63 \times 1.4$ oil differential interference contrast objective on the LSM 510 confocal microscope and fluorescence was analyzed with LSM META Acquisition and Image Browser software (both from Carl Zeiss, Le Pecq, France).

For ChTRase staining in mouse tissues, formalin-fixed, paraffin-embedded lungs were subjected to mild heat-induced antigen retrieval and reacted with $10 \mu \mathrm{g} / \mathrm{ml}$ rabbit polyclonal anti-ChTRase Ab. Binding was visualized using biotin-conjugated anti-rabbit $\mathrm{Ab}$ and avidin-biotinylated peroxidase complex from the Vectastain kit (Vector) followed by incubation with 3,3'-diaminobenzidine (DakoCytomation) and light Mayer's hematoxylin counterstaining.

\section{Alveolar Macrophage Isolation and Stimulation}

Alveolar macrophages were isolated from the BAL obtained from 8 healthy never-smokers, 10 smokers without COPD, and 14 smokers with COPD (Global Initiative for Obstructive Lung Disease stages [II], $n=11$, and III $[n=3])$ who underwent bronchoscopy. ${ }^{14}$ Smokers with 
COPD were former $(n=8)$ or current smokers $(n=6)$. BAL cells were resuspended in RPMI- 1640 medium containing $25 \mathrm{mmol} / \mathrm{L}$ Hepes, $2 \mathrm{mmol} / \mathrm{L}$ glutamine, 2.5 $\mathrm{mmol} / \mathrm{L}$ sodium pyruvate, non-essential amino acids, 100 $\mathrm{IU} / \mathrm{ml}$ penicillin, and $100 \mu \mathrm{g} / \mathrm{ml}$ streptomycin (all from Invitrogen, Cergy-Pontoise, France) and were seeded at 500,000 macrophages $/ \mathrm{ml}$ in 12-well plates (CorningCostar, Acton, MA). After 2 hours at $37^{\circ} \mathrm{C}$ in a humidified $5 \% \mathrm{CO}_{2}$ incubator, cells were washed and further incubated for 24 hours, when they were either collected for RNA isolation, or stimulated over 24 hours with $0.1,1$, and $10 \mu \mathrm{g} / \mathrm{ml}$ of ChTRase, or with $10 \mathrm{ng} / \mathrm{ml}$ of recombinant human tumor-necrosis factor (TNF)- $\alpha$ (R\&D Systems, Minneapolis, MN), or with the medium alone. In all experiments, cell-free supernatants were collected and stored at $-80^{\circ} \mathrm{C}$ until use.

\section{Quantitative Real-Time PCR}

Total RNA was extracted from alveolar macrophages using the Nucleospin RNA II kit (Macherey-Nagel, Hoerdt, France) and reverse transcribed using Moloney Murine Leukemia Virus enzyme (Invitrogen). The levels of the transcripts encoding ChTRase were assessed by quantitative real-time PCR (Mx 3000P apparatus, Stratagene Europe, Amsterdam, The Netherlands), and their expression was normalized to that of ubiquitin $\mathrm{C}$, using GeNorm software. ${ }^{17}$ Primers (ChTRase, GenBank Identifier NM_003465, sense 5'-CTGCATCATGGTGCGGTC-3', antisense, 5'-GTGCTCAGCTGGTGGTTG-3'; ubiquitin C (GenBank Idenfier NM_004168), sense, 5'CACTTGGTCCTGCGCTTGA-3', antisense, 5' - TTTTGGGAATGCAACAACTTT-3') were designed using Primer Express 2 Software (Applied Biosystems, Framingham, MA) and were synthesized by Genosys (Sigma). Their sequences were blasted against Basic Local Alignment Search Tool database (http://www.ncbi.nlm.nih.gov/ BLAST).

\section{Mediator Assessment}

BAL levels of interleukin (IL) $-1 \beta$, IL-8, TNF- $\alpha$, soluble type II receptor of TNF- $\alpha$ (TNF-RII), granulocyte-macrophage colony-stimulating factor, and interferon- $\gamma$ were assessed using the multianalyte LabMAP Luminex technology (Luminex Corp., Austin, TX), which allows simultaneous assessment of multiple protein markers in biological samples. ${ }^{18}$ Sensitivities were of $0.5 \mathrm{pg} / \mathrm{ml}(\mathrm{IL}-1 \beta)$, $0.7 \mathrm{pg} / \mathrm{ml}$ (IL-8), $0.5 \mathrm{pg} / \mathrm{ml}$ (TNF- $\alpha$ ), $0.6 \mathrm{pg} / \mathrm{ml}$ (TNF-RII), $10 \mathrm{pg} / \mathrm{ml}$ (granulocyte-macrophage colony-stimulating factor), and $0.9 \mathrm{pg} / \mathrm{ml}$ (interferon- $\gamma$ ). Chitinolytic activity of purified human ChTRase and of BAL fluid was tested using 4-methylumbelliferyl- $\beta$-D-N, $N^{\prime}, N^{\prime}$ '-triacetylchitotriose as a substrate and the fluorescence of released 4-methyl-umbelliferone was measured. ${ }^{9}$ Reactions were performed at two different $\mathrm{pH}$ values (7.0 and 3.5). For inhibition experiments, BAL samples, or human purified ChTRase $(0.005$ to $10 \mathrm{ng} / \mathrm{ml})$ was pre-incubated for 15 minutes at room temperature with the polyclonal rabbit anti-ChTRase $A b$, before the addition of the substrate and chitinolytic activity was assessed, as described above. Human ChTRase and AMCase were measured by the corresponding specific ELISA assays, which were developed on site (Supplementary Figure S1A at $h$ ttp:// ajp.amjpathol.org).

The levels of IL-8 and monocyte-chemoattractant protein (MCP)-1 in the supernatant of alveolar macrophages were assessed by ELISA (R\&D Systems) and MMP-9 was measured by the specific Biotrak activity assay (GE Health Care). The detection levels were 6.5 $\mathrm{pg} / \mathrm{ml}$ (IL-8), $12.5 \mathrm{pg} / \mathrm{ml}$ (MCP-1), and $250 \mathrm{pg} / \mathrm{ml}$ (MMP-9).

\section{In Vivo Experiments}

Adenoviral vector carrying full-length ChTRase (ChTRase AdV) and control empty vector adenovirus (Null Adv) were generated using the AdEasy system using protocols previously described by Stratagene. ${ }^{19}$ Briefly, murine ChTRase was cloned into the pCMVShuttle plasmid and recombination performed in the bacterial $E$. coli strain BJ5183-Ad1, to obtain adenoviral genome plasmid. This plasmid was then transfected into Ad 293 cells to generate virus. Virus was scaled-up in 293F cells (Invitrogen) and purified by cesium chloride gradient centrifugation. Titer was determined by Tissue Culture Infective Dose 50 on Ad 293 cells. Null AdV with no insert was produced in the same way.

Female BALB/c mice, aged 8-10 weeks (Harlan Corporation, Indianapolis, IN) were anesthetized with isoflurane (Baxter Health Care Corporation, Deerfield, IL) and instilled intranasally with $50 \mu \mathrm{l}$ PBS alone, or supplemented with $10^{7}$ Plaque-Forming Units of ChTRase Adv, or Null Adv. Two or 4 days thereafter, mice were sacrificed with a barbiturate overdose and bled by cardiac puncture. BAL was performed with $3 \times 0.6 \mathrm{ml}$ aliquots of Hepes-buffered saline, containing $10 \mathrm{mmol} / \mathrm{L}$ HEPES and EDTA, via a tracheal catheter. BAL fluid was centrifuged $\left(400 \times g, 10\right.$ minutes, $\left.4^{\circ} \mathrm{C}\right)$ and the cells removed. Total cell counts were determined using a Coulter Z1 particle counter (Beckman Coulter Corporation, Brea, CA) and differential cell counts (of at least 500 cells per slide) were performed on cytospin preparations stained with eosin and methylene blue (Diff-Quik, Dade Diagnostics, Duedingen, Switzerland). Lung tissue was homogenized (100 $\mathrm{mg} / \mathrm{ml}$ ) in Hepes-buffered saline containing protease inhibitors (Complete EDTA-free tablets, Roche, Nutley, $\mathrm{NJ})$ and centrifuged, $\left(800 \times \mathrm{g}, 10\right.$ minutes, $\left.4^{\circ} \mathrm{C}\right)$, and the supernatant collected and stored alongside with BAL fluid supernatants at $-80^{\circ} \mathrm{C}$ until the assessment of the murine homologue of IL-8, keratinocyte-derived cytokine (KC) and MCP-1 by ELISA (R\&D Systems). The minimum detection levels for both assays were $2 \mathrm{pg} / \mathrm{ml}$. In separate experiments, mice were terminally anesthetized and the left lung lobe was dissected, fixed in $4 \%$ formaldehyde, and embedded in paraffin, and $5-\mu \mathrm{m}$ serial sections were used to examine the localization of ChTRase by immunohistochemistry. The right lobe was kept for RNA purification using the RNAeasy Plus mini kit (Qiagen, Valencia, CA). Complementary DNA was syn- 
thesized using Sprint Power Script Double Preprimed 96 kit (Clontech Laboratories, Mountain View, CA) and the levels of the transcripts encoding ChTRase, AMCase, KC, MCP-1 and the reference gene, glyceraldehyde-3phosphate dehydrogenase, were measured by TaqMan real-time PCR (Applied Biosystems).

\section{Statistical Analysis}

Data were analyzed statistically using the GraphPad Prism software version 4.0 for Maclntosh (GraphPad Software, Inc. San Diego, CA). The results are expressed as median (interquartile range), except those obtained with purified alveolar macrophages and with Adv-treated mice, which represent means \pm SEM. Since the data were not normally distributed, non-parametric Kruskal-Wallis test was used to compare the different groups of subjects. When an overall significant difference was detected $(P \leq 0.05)$, pair wise group tests were performed using the MannWhitney U-test. Univariate regression analyses were performed by the Spearman's rank-order method and correlation coefficients $\left(r^{2}\right)$ were calculated. To account for multiple tests, a Benjamini and Hochberg correction with a family-wise error rate of 0.05 was used. ${ }^{14}$ In all cases, $P$ values $\leq 0.05$ were considered significant.

\section{Results}

\section{BAL Chitinolytic Activity and Levels of ChTRase in Subjects with COPD and Asthma}

Smokers with COPD had higher chitinolytic activity in their BAL fluid than smokers without COPD and neversmokers (Figure 1A). Chitinolytic activity was detectable at a pH of 7.0, but not at a pH of 3.5 (data not shown). Using a polyclonal $\mathrm{Ab}$ that selectively inhibits ChTRase activity in an enzymatic assay (Figure 1B), we established that the presence of ChTRase accounted for $65 \%$ and $80 \%$ of the BAL chitinolytic activity in smokers and in COPD patients, respectively (Figure 1C). These data were further supported by the observation that ChTRase levels were higher in the BAL from COPD patients than in smokers without COPD (Figure 1D), whereas AMCase was below the detection limit of the ELISA (data not shown). Furthermore, patients with COPD, either current or former smokers ( $n=17$ and 13, respectively), had comparable BAL chitinolytic activity $(P=0.276)$ and levels of ChTRase $(P=0.273)$. To determine whether the observed differences in BAL chitinolytic activity and levels of ChTRase were associated selectively with COPD, we analyzed in parallel a group of subjects with asthma of different severity. In these subjects, BAL chitinolytic activity and levels of ChTRase were comparable with those measured in healthy controls (Figure 1, A and D).

Analyses by Spearman's regression of values obtained in smokers with and without COPD showed a high and significant correlation between chitinolytic activity or levels of ChTRase, on one hand, and values of \% predicted pre- and post-bronchodilator forced expiratory volume in 1 second, pre-bronchodilator forced expiratory volume in
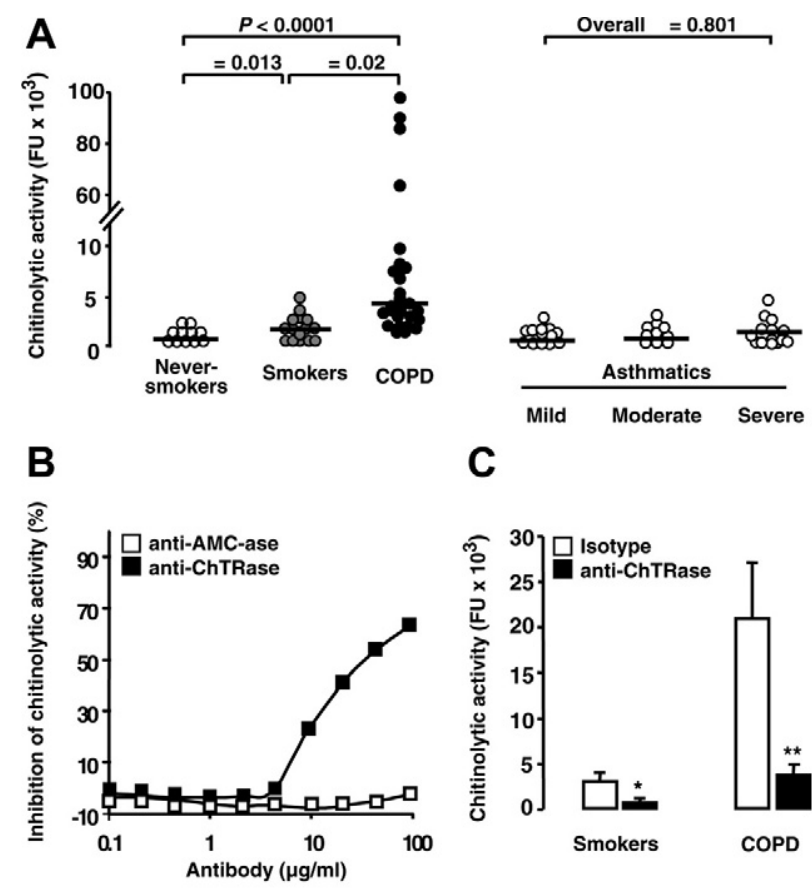

C
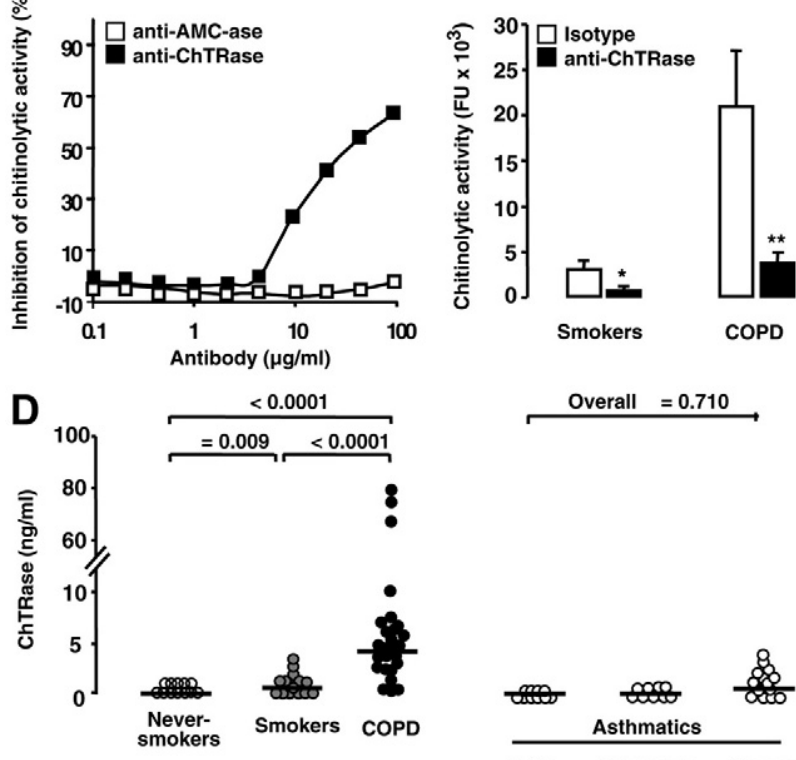

Figure 1. BAL chitinolytic activity and levels of ChTRase in subjects with COPD and asthma. A: Chitinolytic activity (in fluorescence units, FU) in BAL samples collected by fiberoptic bronchoscopy in never-smokers, in smokers, in COPD patients, and in mild, moderate and severe asthmatics (horizontal bars denote median values). B: Inhibition, by a neutralizing anti-ChTRase $\mathrm{Ab}$ (closed squares), but not by an anti-AMCase Ab (open squares), of chitinolytic activity induced by $25 \mathrm{ng} / \mathrm{ml}$ of recombinant human ChTRase in an enzymatic assay. C: Inhibition of chitinolytic activity in BAL samples from smokers and from patients with COPD by a neutralizing ChTRase Ab (closed squares), but not by its control rabbit IgG isotype (open squares). Columns represent means \pm SEM of $n=6$ to 10 independent experiments in each group. ${ }^{*} P=0.03,{ }^{* *} P=0.02$. D: BAL levels of ChTRase in never-smokers, in smokers, in patients with COPD, and in mild, moderate and severe asthmatics. Horizontal bars in panels (A) and (D) denote median values.

1 second /forced ventricular capacity and transfer factor of the lung for carbon monoxide, on the other hand (Table 1). Neither chitinolytic activity, nor the levels of ChTRase in the BAL fluid of smokers with and without COPD correlated with smoking history, measured in packs of cigarettes per year (Table 1).

\section{BAL Cytokines, Chemokines, and Receptors}

The amounts of IL-1 $\beta$, IL- 8 , TNF- $\alpha$, and TNF-RII, whose assessment reflects the bioactivity of TNF- $\alpha,{ }^{20}$ were elevated in BAL from patients with COPD, as compared to smokers without COPD, or to never-smokers (Table 2). Under these conditions, granulocyte-macrophage colony-stimulating factor, and interferon- $\gamma$ were undetectable. 
Table 1. Correlation Analyses with Clinical Parameters*

\begin{tabular}{|c|c|c|c|c|}
\hline \multirow[b]{2}{*}{ Parameter } & \multicolumn{2}{|c|}{$\begin{array}{l}\text { Chitinolytic } \\
\text { activity in BAL }\end{array}$} & \multicolumn{2}{|c|}{$\begin{array}{c}\text { ChTRase in } \\
\text { BAL }\end{array}$} \\
\hline & $r^{2}$ & $P$ value & $r^{2}$ & $P$ value \\
\hline $\begin{array}{l}\text { Pre- } \beta 2 \text { agonist FEV } \\
\quad(\% \text { predicted })\end{array}$ & 0.520 & $0.0286^{\dagger}$ & 0.706 & 0.0002 \\
\hline $\begin{array}{l}\text { Post- } \beta 2 \text { agonist FEV } \\
\text { ( } \% \text { predicted })\end{array}$ & 0.473 & 0.0390 & 0.697 & 0.0002 \\
\hline $\begin{array}{l}\text { Pre- } \beta 2 \text { agonist } \mathrm{FEV}_{1} / \\
\quad \text { FVC }(\%)\end{array}$ & 0.612 & 0.0036 & 0.701 & 0.0001 \\
\hline FRC (\% predicted) & 0.474 & 0.0497 & 0.288 & 0.0222 \\
\hline RV (\% predicted) & 0.279 & 0.2974 & 0.210 & 0.0737 \\
\hline TLC (\% predicted) & 0.491 & 0.0479 & 0.533 & 0.0240 \\
\hline $\mathrm{DL}_{\mathrm{CO}}(\%$ predicted $)$ & 0.542 & 0.0239 & 0.706 & 0.0002 \\
\hline $\begin{array}{l}\text { Smoking history } \\
\text { (packs/year) }\end{array}$ & 0.271 & 0.1705 & 0.183 & 0.2320 \\
\hline
\end{tabular}

A high positive correlation was found between both BAL chitinolytic activity and ChTRase and levels of IL-1 $\beta$, IL-8, TNF- $\alpha$, and TNF-RII (Table 3). Finally, BAL chitinolytic activity and levels of ChTRase were correlated with each other $\left(r^{2}=0.970, P<0.0001\right)$.

\section{Immunolocalization of ChTRase in the Airways}

To determine the potential cell sources of ChTRase in the airways, we next investigated the expression of this enzyme by immunohistochemistry in both endobronchial biopsy samples and lung tissue specimens collected from patients undergoing lung resection surgery. Neversmokers had very few if any ChTRase-positive cells in their bronchial biopsies (Figure 2, A and B). In smokers without COPD, the number of cells expressing ChTRase was higher and was further augmented in smokers with COPD (Figure 2, A and B). ChTRase localized mainly in cells infiltrating the bronchial epithelium and the submucosa and was not detected in the bronchial epithelium, the vascular endothelium and the airway smooth muscle (Figure 2B, and data not shown). In contrast, the number of AMCase-expressing cells was very low in never-smokers (median [interquartile range], $3.9 \mathrm{cells} / \mathrm{mm}^{2}$ [2.2 to 6.4]) and did not vary significantly across the three patient groups (overall $P=0.92$ ). Double immunofluorescence, followed by confocal microscopy, demonstrated that ChTRase-expressing cells in bronchial biopsies were
Table 3. Correlation Analyses with BAL Cytokines, Chemokines, and Receptors*

\begin{tabular}{cccccr}
\hline & \multicolumn{2}{c}{$\begin{array}{c}\text { Chitinolytic } \\
\text { activity in BAL }\end{array}$} & & \multicolumn{2}{c}{$\begin{array}{c}\text { ChTRase levels } \\
\text { in BAL }\end{array}$} \\
\cline { 2 - 3 } \cline { 5 - 6 }$(\mathrm{pg} / \mathrm{ml})$ & $r^{2}$ & $P$ value & & $r^{2}$ & \multicolumn{1}{c}{$P$ value } \\
\hline IL-1 $\beta$ & 0.408 & $0.0022^{\dagger}$ & & 0.422 & 0.0016 \\
IL-8 & 0.411 & 0.0022 & & 0.639 & $<0.0001$ \\
TNF- $\alpha$ & 0.336 & 0.0104 & & 0.456 & 0.0006 \\
TNF-RII & 0.278 & 0.0338 & & 0.549 & $<0.0001$ \\
\hline
\end{tabular}

*Spearman's rank order method (20 smokers and 30 patients with COPD were included).

${ }^{\dagger}$ Bold denotes significant correlation after Benjamini and Hochberg correction.

both macrophages (CD68 staining, Figure 2C) and neutrophils (elastase staining, Figure 2D).

The staining pattern of ChTRase was also determined in the small airways and lung parenchyma by immunohistochemistry and double immunofluorescence, together with confocal microscopy (Figure 3). ChTRase was constitutively expressed in a proportion of alveolar macrophages of never-smokers (Figure 3A). Smokers had a higher number of macrophages containing ChTRase in the alveoli and the interstitium (Figure 3A) and this accumulation was even more pronounced in patients with COPD (Figure 3, B and C, first and second panel). ChTRase was also markedly up-regulated in the bronchiolar epithelium of COPD patients (Figure 3, B and C, third panels), but failed to be expressed by type I or II pneumocytes (Figure 3A, first panel and Figure 3B, second panel). No immunostaining was observed when tissue sections were incubated with control rabbit IgG (Figure $3 \mathrm{C}$, last right panel), or with the primary Ab previously absorbed with purified ChTRase (data not shown).

\section{Expression and Production of ChTRase by Alveolar Macrophages}

Because macrophages were found to be major ChTRase-positive cells in the airways, we next determined whether expression of this enzyme was differentially regulated according to the disease status of the donors. Immunostaining of BAL cells revealed faint expression of ChTRase in the cytosol of alveolar macrophages of never-smokers, a consistent increment in smokers without COPD and a strong immunostaining in smokers with COPD (Figure 4A). A significantly higher proportion of ChTRase-positive alveolar macrophages

Table 2. Levels of Cytokines, Chemokines, and Receptors in BAL Fluid

\begin{tabular}{ccccc}
\hline $\begin{array}{c}\text { Mediator in BAL } \\
(\mathrm{pg} / \mathrm{ml})\end{array}$ & $\begin{array}{c}\text { Never-smokers } \\
(n=20)\end{array}$ & $\begin{array}{c}\text { Smokers without COPD } \\
(n=20)\end{array}$ & $\begin{array}{c}\text { Smokers with COPD } \\
(n=30)\end{array}$ & $P$ value* \\
\hline IL-1 $\beta$ & $0.72(0.50-1.30)^{\dagger}$ & $1.35(0.70-3.74)^{\ddagger}$ & $1.85(1.18-4.86)^{\ddagger}$ & 0.0141 \\
IL-8 & $28.5(21.0-61.8)$ & $54.5(40.2-68.5)^{\ddagger}$ & $136.5(66.8-380.8)^{\ddagger \S}$ & $<0.0001$ \\
TNF- $\alpha$ & $0.99(0.87-1.05)$ & $0.68(0.62-0.83)^{\ddagger}$ & $0.81(0.67-1.08)^{\S}$ & 0.0134 \\
TNF-RII & $32.8(8.6-43.3)$ & $1.7(1.5-2.4)^{\ddagger}$ & $61.7(44.2-117.0)^{\ddagger \S}$ & 0.0011 \\
\hline
\end{tabular}

*Significance was assessed with the use of Kruskal-Wallis test.

${ }^{\dagger}$ Results are expressed as median (interquartile range).

${ }^{\ddagger} P<0.05$, as compared to never-smokers, ${ }^{\S} P<0.05$, as compared to smokers without COPD (Mann-Whitney $U$ test). 
A

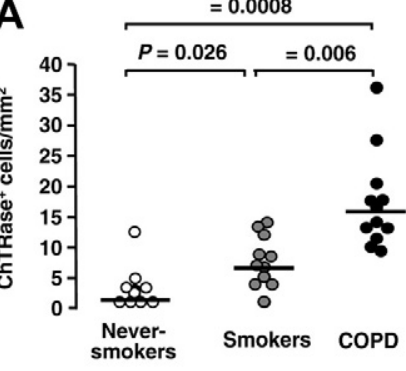

C

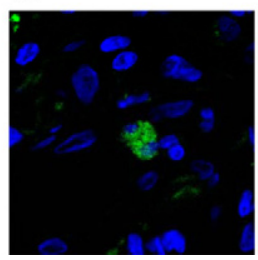

B

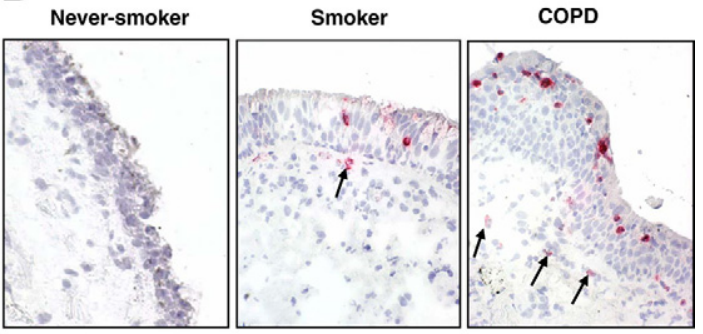

D
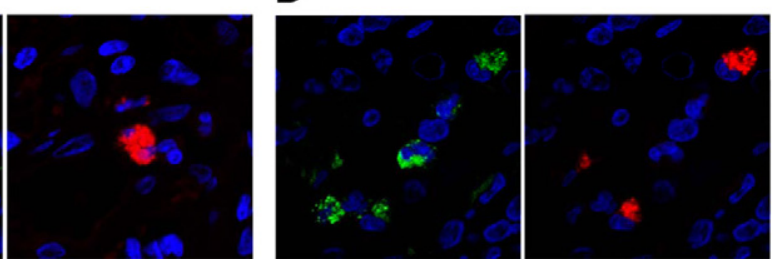

Figure 2. Expression of ChTRase in bronchial biopsies. A: Number ChTRase-positive cells per $\mathrm{mm}^{2}$ of bronchial biopsies in never-smokers, in smokers, and patients with COPD (horizontal bars denote median values). B: ChTRase (red chromogen) is undetectable in bronchial tissue sections from never-smokers, whereas faint ChTRase-positive cells are identified in the bronchial epithelium and the submucosa (arrow) of smokers. In smokers with COPD, substantially more ChTRase-positive cells infiltrate the bronchial epithelium (arrows) and the subepithelial areas. Original magnification, $\times 40$. $\mathbf{C}$ and $\mathbf{D}$ : Double immunofluorescent labeling of bronchial tissue sections of a patient with COPD showing ChTRase- (red, right panels) expressing CD68 (green, left panel in C)-positive macrophages and elastase (green, left panel in D)-positive neutrophils. Original magnification, $\times 189$ ). was found in smokers without COPD, as compared to never-smokers (Figure 4B). This proportion was further increased in smokers with COPD, where approximately $80 \%$ of macrophages expressed ChTRase (Figure 4B). When present, polynuclear neutrophils also stained positively for ChTRase (data not shown).

ChTRase expression was also assessed at the mRNA level in BAL alveolar macrophages isolated by adherence. Analysis by quantitative real-time PCR showed that the levels of ChTRase mRNA, normalized according to the amounts of ubiquitin $\mathrm{C}$, were higher in alveolar macrophages of smokers without COPD than in never-smokers and were further enhanced in smokers with COPD (Figure 4C, left panel). Under these conditions, the levels of ubiquitin $\mathrm{C}$ mRNA did not vary significantly in alveolar macrophages from the three patient groups (mean values of cycle threshold comprised between 16.1 \pm 0.5 and 16.6 \pm 0.3 , overall $P=0.179$ ). In addition, alveolar macrophages from smokers with and without COPD that had been cultured for 24 hours in the presence of the medium alone released spontaneously higher amounts of ChTRase than those from never-smokers (Figure 4C, right panel). Exposure of alveolar macrophages for 24 hours to $10 \mathrm{ng} / \mathrm{ml}$ of TNF- $\alpha$ up-regulated the levels of secreted ChTRase in smokers with COPD, but not in smokers without COPD, or in never-smokers (Figure 4C, right panel).

\section{Effect of ChTRase on Alveolar Macrophages}

We next examined the ability of ChTRase to activate alveolar macrophages from healthy or diseased donors (Figure 5 and Supplementary Figure S2, at http:// ajp.amjpathol.org). Alveolar macrophages from smokers with and without COPD spontaneously produced more IL-8 and MCP-1 than those from never-smokers (Figure 5, $A$ and B). Stimulation of the cells for 24 hours with $0.1,1$
A

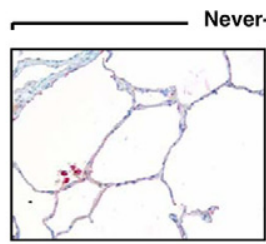

B

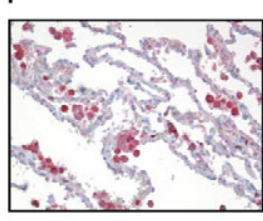

C

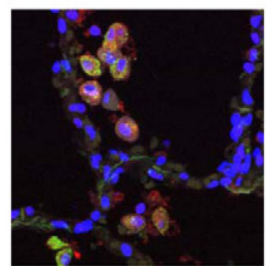

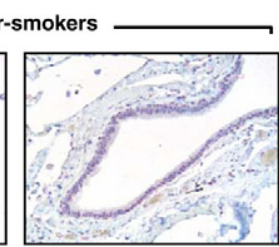

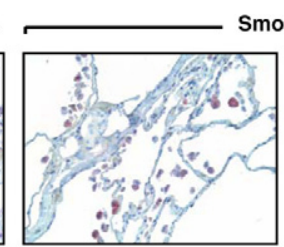

Smokers

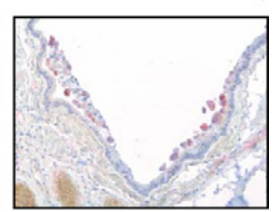

COPD
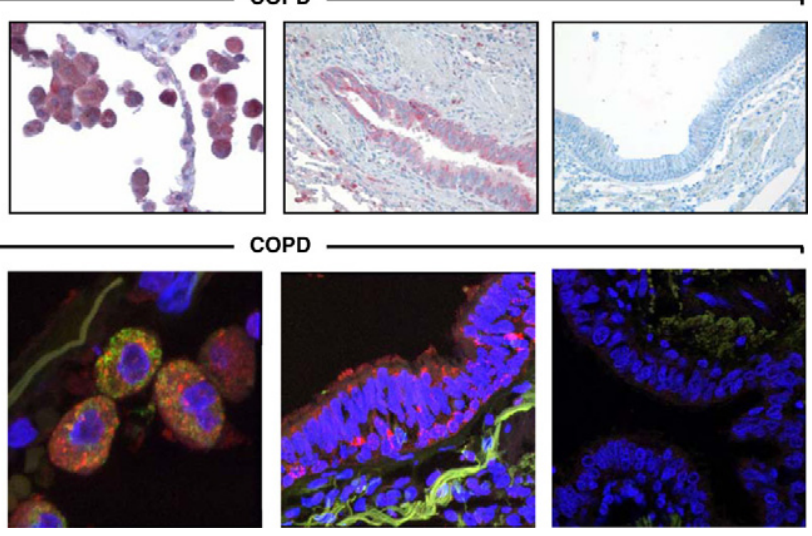

Figure 3. Expression of ChTRase in lung tissues. A: Never-smokers show scant ChTRase-positive cells (red chromogen) in the alveolar septa and no immunostaining in the bronchiolar epithelium. Smokers have ChTRase-expressing macrophages in the alveoli and at the vicinity of the bronchiolar epithelium, but no immunostaining in the bronchiolar epithelium. B: Patients with COPD have prominent accumulation of ChTRase-positive macrophages in the alveoli and strong expression of ChTRase in the bronchiolar epithelium. The last right panel showing the absence of immunostaining in a control isotype (rabbit IgG)-labeled lung tissue section from a patient with COPD. Original objective $\times 20$, except the second panel in $(\mathbf{B}$ $\times 40$ ). C: Double immunofluorescence labeling of lung tissue sections of a patient with COPD shows ChTRase- (red) and CD68 (green)-positive macrophages and immunolocalization of ChTRase (red) in the bronchiolar epithelium. Last right panel represents a control-isotypelabeled tissue section with no staining. Original objective $\times 63$, except in the second panel (×189). 
A Never-smoker

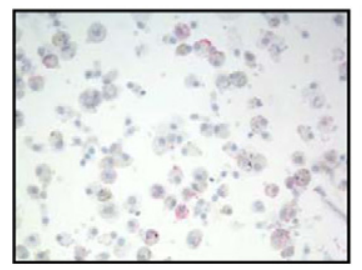

C

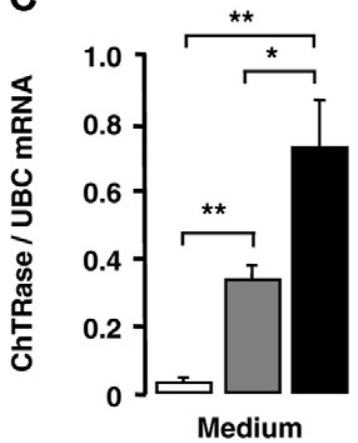

Smoker

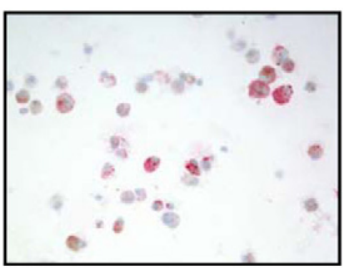

COPD
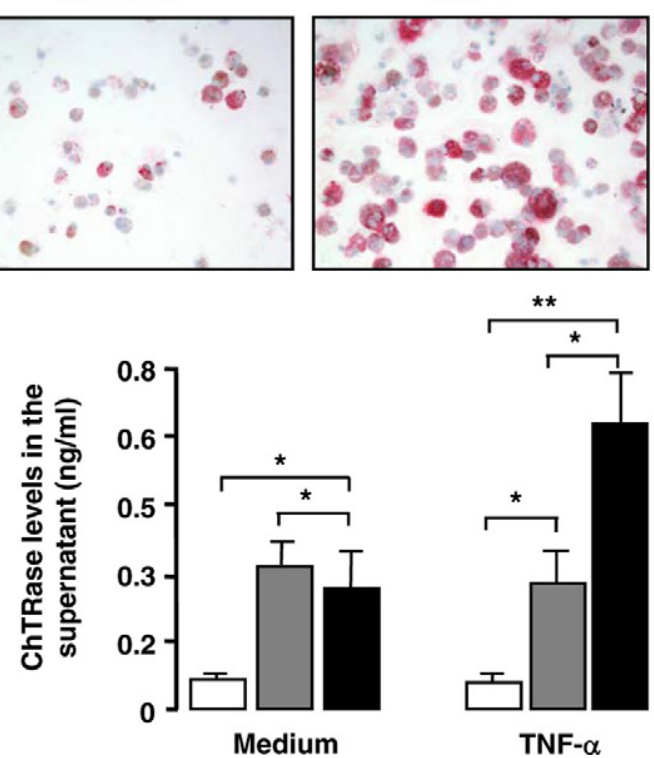

B

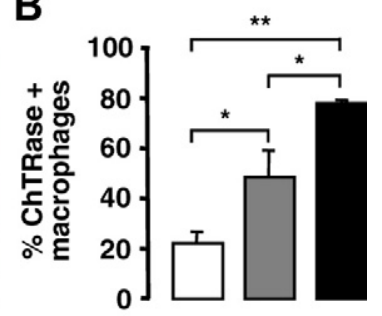

Figure 4. Expression and functional role of ChTRase in alveolar macrophages. A: The expression of ChTRase (red chromogen) is higher in alveolar macrophages collected by BAL from patients with COPD, as compared to smokers and to never-smokers. Original magnifications $\times 40$. B: Mean proportions of alveolar macrophages expressing ChTRase in never-smokers (open column), in smokers (gray column) and in patients with COPD (closed column). Results are means \pm SEM of $n=8$ to 10 distinct cell preparations in each group. ${ }^{*} P<0.05$, ${ }^{* *} P<0.03$ (Kruskal-Wallis and Mann-Whitney $U$-tests). (C, left) Levels of ChTRase mRNA (ratio over the amounts of the housekeeping gene, ubiquitin C, UBC) in freshly isolated alveolar macrophages from never-smokers (open bars), from smokers (gray bars) and from patients with COPD (closed bars). (C, right) Spontaneous and TNF- $\alpha$ (10 ng/ml for 24 hours)-induced ChTRase release from alveolar macrophages from never-smokers, smokers and COPD patients. Data are means \pm SEM of $n=10$ to 12 distinct cell preparations in each group of subjects. ${ }^{*} P<0.04,{ }^{* * *} P<0.03$.

(Supplementary Figure S2, at http://ajp.amjpathol.org) and $10 \mu \mathrm{g} / \mathrm{ml}$ (Figure 5) of ChTRase promoted a dosedependent release of IL-8 and MCP-1. Maximal chemokine release was seen at $10 \mu \mathrm{g} / \mathrm{ml}$ of ChTRase and, at this concentration, this chitinase was as potent as TNF- $\alpha$, used as a positive internal control (Figure 5, A and B). Spontaneous production of active MMP-9 by mediumexposed alveolar macrophages from smokers with and without COPD was highly variable (between 0.3 and 11.9 $\mathrm{ng} / \mathrm{ml}$ ) and, therefore, the effect of ChTRase and TNF- $\alpha$ on MMP-9 secretion was calculated as a percentage of release over medium-exposed cells. At $10 \mu \mathrm{g} / \mathrm{ml}$, ChTRase induced 1.2-, 1.4-, and 1.9-fold release of active MMP-9 from alveolar macrophages from neversmokers, from smokers without COPD and from smokers with COPD, respectively (Figure 5C). The effect of
ChTRase was similar to that induced by TNF- $\alpha$ (2.1-fold release, Figure 5C).

\section{Effect of ChTRase Overexpression in the Mouse Lung}

To establish whether ChTRase over expression in the lung promotes features of inflammation seen in COPD, we next compared BAL cell composition and the synthesis of $\mathrm{KC}$ and MCP-1 in normal mice that had received ChTRase Adv, or a control empty vector AdV (Null Adv), administered by the intranasal route. The expression of ChTRase mRNA increased by more than 20-fold at days 2 and 4 following ChTRase Adv administration (Figure $6 A$ ) and returned to basal levels by day 10 (data not
A

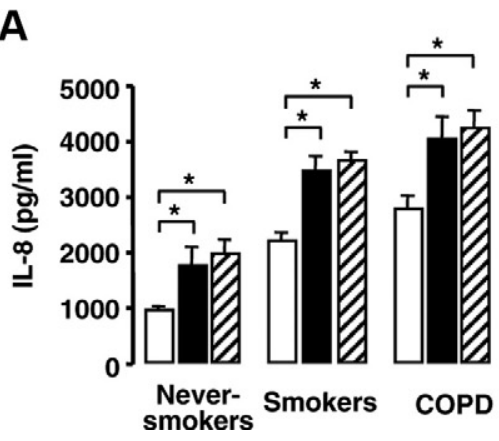

B

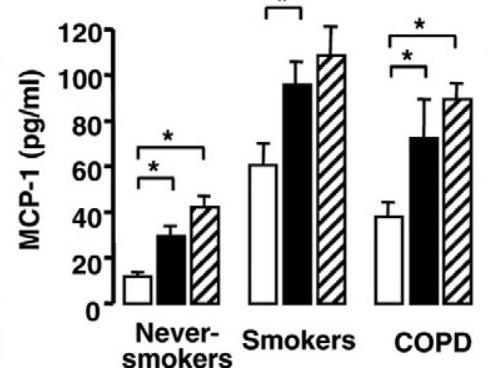

C

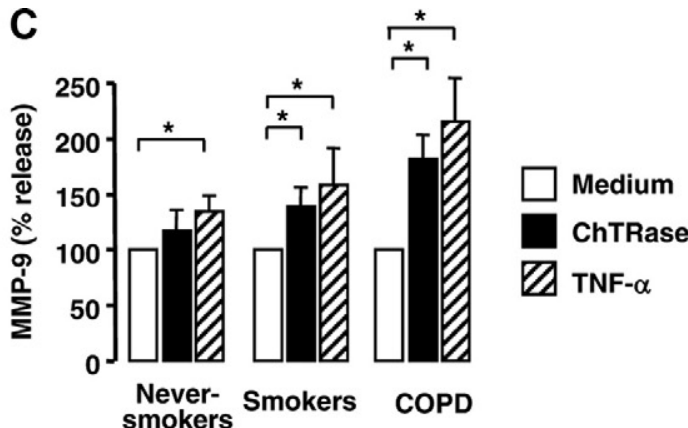

Figure 5. ChTRase induces IL-8, MCP-1, and MMP-9 release by alveolar macrophages. Alveolar macrophages from never-smokers, from smokers, and from patients with COPD were stimulated over 24 hours with the medium alone (open columns), or supplemented with $10 \mu \mathrm{g} / \mathrm{ml} \mathrm{ChTRase}$ (closed bars), or with 10 $\mathrm{ng} / \mathrm{ml} \mathrm{TNF}-\alpha$ (hatched bars) and the levels of IL- 8 (A), MCP-1 (B), and MMP-9 (C) were determined by ELISA. Data are means \pm SEM of $n=5$ to 7 independent experiments in each group. ${ }^{*} P<0.05$ (Kruskal-Wallis and Mann-Whitney $U$-test). 
A

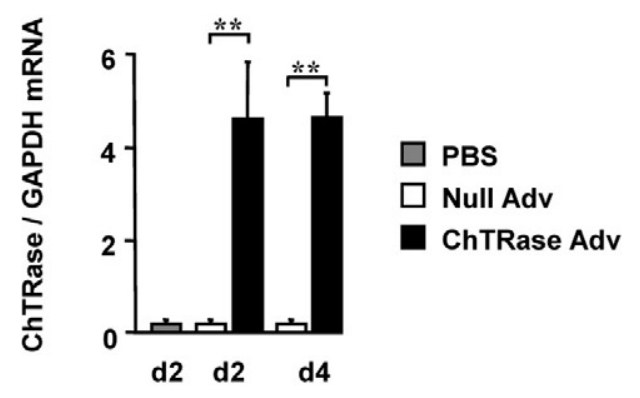

C

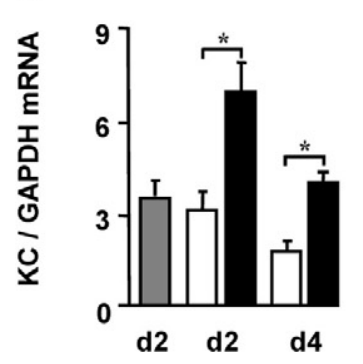

B

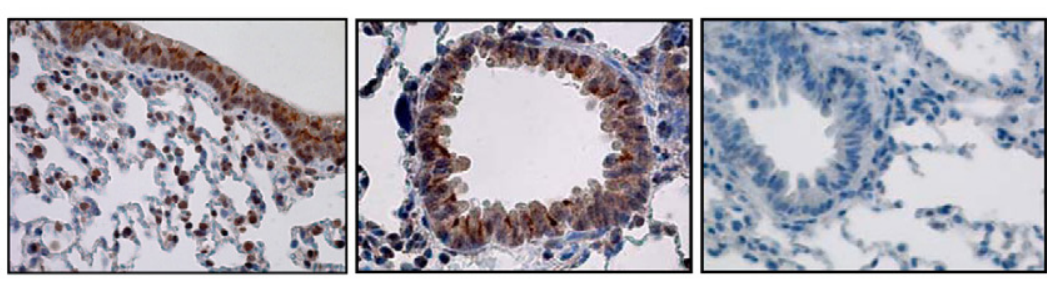

D

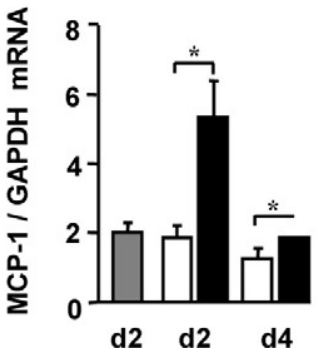

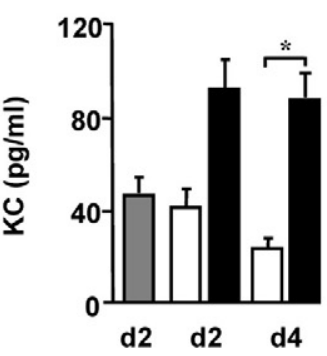

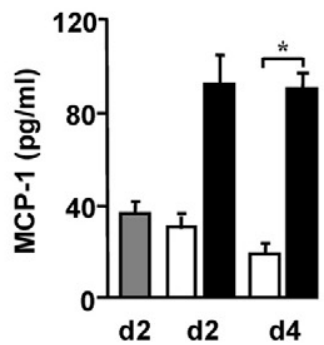

Figure 6. Pulmonary ChTRase overexpression promotes airway inflammation in normal mice. A: Levels of ChTRase mRNA (ratio over the amounts of the housekeeping gene, glyceraldehyde-3-phosphate dehydrogenase) in whole lung homogenates obtained from normal mice that had been instilled intranasally with PBS, or with empty vector adenovirus (Null Adv), or with adenovirus carrying full-length ChTRase (ChTRase Adv). Mice were sacrificed 2 or 4 days thereafter. Data are means \pm SEM of $n=3$ to 7 independent experiments. (** $P<0.01$ ). B: ChTRase immunolocalization (brown deposit) in bronchial and bronchiolar epithelium and in tissue macrophages contained in lung tissue sections from ChTRase Adv-instilled mice sacrificed at 4 days. The right panel shows an exemplary isotype-stained tissue section. Original magnification, $\times 40$. C: Levels of KC and MCP-1 (ratio over glyceraldehyde-3-phosphate dehydrogenase mRNA) in whole lung homogenates from PBS-, Null Adv-, and ChTRase Adv-instilled mice. D: Amounts of KC and MCP-1, as determined by ELISA in BAL fluid from PBS-, or Null Adv-, or ChTRase Adv-instilled mice. Data in $(\mathbf{C})$ and $(\mathbf{D})$ are means \pm SEM of $n=3$ to 7 independent experiments $\left({ }^{*} P<0.02\right)$.

shown). Under these conditions, the lung levels of AMCase mRNA were not altered (data not shown). The amounts of mRNA encoding the housekeeping gene, glyceraldehyde-3-phosphate dehydrogenase, were similar in lungs from PBS-, Null AdV- and ChTRase AdVinstilled mice (mean values of cycle threshold comprised between $19.5 \pm 0.06$ and $20.2 \pm 0.02$, overall $P=0.241$ ). By immunohistochemistry, we found that in ChTRase-Adv treated mice, this chitinase localized mainly in the bronchial and bronchiolar epithelium and in tissue macrophages (Figure 6B). ChTRase overexpression significantly increased the number of total cells and of alveolar macrophages in BAL fluid at day 2 and 4, without altering neutrophil and lymphocyte counts (Table 4). ChTRase Adv-instilled mice also exhibited higher lung levels of the transcripts encoding $\mathrm{KC}$ and MCP-1 at day 2 and, to a lesser extent, at day 4, than their Null Adv-treated counterparts (Figure 6C). This was accompanied by elevated amounts of KC and MCP-1 in BAL fluid at both days 2 and 4 (Figure 6D).

\section{Discussion}

In the current study, we demonstrate that smokers with COPD have significantly higher chitinolytic activity in their BAL fluid than smokers without COPD, or never-smoker healthy individuals. Using specific Abs that selectively inhibit ChTRase activity, we found that this enzyme accounted for approximately $80 \%$ of the BAL chitinolytic activity found in smokers with COPD. The residual 20\% activity is most likely a result of incomplete inhibition by the anti-ChTRase neutralizing Ab in dose-response enzymatic assay. Nevertheless, since the chitinolytic enzyme assay is more sensitive for detecting AMCase than is the ELISA, we cannot at present rule out that the

Table 4. Effect of a Single Intranasal Instillation of ChTRase Adv to Naive Mice on BAL Cell Composition

\begin{tabular}{|c|c|c|c|c|c|}
\hline \multirow[b]{2}{*}{ Treatment } & \multirow[b]{2}{*}{ Day after treatment } & \multicolumn{4}{|c|}{ Cell type $\left(\times 10^{5} / \mathrm{ml}\right.$ BAL $)$} \\
\hline & & Total cells & Macrophages & Neutrophils & Lymphocytes \\
\hline PBS & 4 & $3.83 \pm 0.41$ & $1.87 \pm 0.25$ & $0.011 \pm 0.004$ & $0.016 \pm 0.010$ \\
\hline Null Adv & 2 & $2.80 \pm 0.54$ & $1.17 \pm 0.13$ & $0.157 \pm 0.113$ & $0.043 \pm 0.016$ \\
\hline ChTRase Adv & 2 & $4.80 \pm 0.50^{*}$ & $2.31 \pm 0.21^{*}$ & $0.058 \pm 0.023$ & $0.025 \pm 0.019$ \\
\hline Null Adv & 4 & $3.22 \pm 0.40$ & $1.73 \pm 0.53$ & $0.032 \pm 0.017$ & $0.002 \pm 0.001$ \\
\hline ChTRase Adv & 4 & $5.27 \pm 0.56^{\star \star}$ & $2.99 \pm 0.58^{*}$ & $0.045 \pm 0.045$ & $0.000 \pm 0.000$ \\
\hline
\end{tabular}

Data are means \pm SEM of $n=3$ to 7 mice per group

${ }^{\star} P<0.02,{ }^{* \star} P<0.01$ (Mann-Whitney $U$ test), for ChTRase AdV, as compared to Null Adv-treated mice. 
residual activity in the BAL is due to the presence of AMCase. However, previous studies have shown that ChTRase is inactive at low $\mathrm{pH}$, while AMCase retains part of its activity. ${ }^{21}$ Our observation that BAL chitinolytic activity is inhibited by low $\mathrm{pH}$ thus argues for a predominant role for ChTRase, rather than AMCase, in smokers with COPD. In addition, the levels of ChTRase, but not of AMCase, were higher in smokers with COPD and they correlated strongly with chitinolytic activity. Finally, the pattern of expression of ChTRase and AMCase was similar in BAL and bronchial biopsies. Thus, the number of ChTRase-positive cells was greater in smokers with COPD than in smokers without COPD, and in neversmokers, whereas very few AMCase-positive cells were found in all tissue preparations, irrespective of the disease status of the donors. These findings extend, in part, recent data demonstrating that BAL cells of smokers and of subjects with mild COPD (but not of subjects with asthma) had higher levels of ChTRase mRNA than healthy donors, without changes in AMCase expression. ${ }^{22}$

Previous studies have shown that a 24-bp duplication polymorphism in exon 10 of the CHIT1 gene results in abnormally spliced mRNA and inactive ChTRase protein deficient in 29 amino acids. ${ }^{23}$ Accordingly, this genetic polymorphism may explain, at least in part, changes in BAL chitinolytic activity that we found in the different groups of subjects. Although, we did not address this issue in the current study, a recent report demonstrated that such a polymorphism did not account for the increase in BAL chitinolytic activity and in ChTRase gene expression observed in smokers and in subjects with mild COPD, as compared to never-smokers and to asthmatics. $^{22}$

Collectively, our findings suggest that ChTRase production in the airways of patients with COPD largely predominates over that of AMCase. These results are in contrast to those obtained in asthma, another chronic respiratory disease that is characterized by airway inflammation and remodeling, ${ }^{24}$ where the expression of AMCase was found to be up-regulated in bronchial biopsy specimens. ${ }^{11}$ Although the basis for this difference is unclear, the cell source(s) and underlying mechanisms involved in AMCase generation in asthma may be distinct from those that produce ChTRase in COPD. In this regard, the epithelium layer appears to be an important source of AMCase in the asthmatic airways, whereas we failed to demonstrate any significant immunostaining in epithelial cells from proximal airways of patients with COPD. It is also of interest that ChTRase has been reported to inhibit the production of AMCase in human monocyte-derived macrophages. ${ }^{21}$ Whether this crossregulation provides an explanation for the differences in the distinct expression profile between ChTRase and AMCase in the airways of patients with COPD remains to be determined. These observations suggest that different patterns of expression of ChTRase and AMCase and, possibly, distinct functions, may distinguish between the underlying mechanisms and pathology in asthma and COPD. This hypothesis is in agreement with recent studies suggesting that genetic polymorphisms in AMCase, but not ChTRase, are associated with bronchial asthma in Caucasian pediatric populations. ${ }^{25,26}$

We have recently shown that, similarly to ChTRase, the chitinase-like protein YKL-40 is up-regulated in BAL and alveolar macrophages from COPD patients, but not asthmatics. ${ }^{14}$ This observation suggests that similar mechanisms are involved in the regulation of ChTRase and YKL-40 expression in COPD. However, little is known concerning the functional relationship and cross-regulation between YKL-40, ChTRase and AMCase, and only very few studies have compared their immunolocalization and release in healthy and diseased cells and tissues, mainly because of the lack of specific reagents.

In a subanalysis performed to account for cigarette smoking, we found similar BAL chitinolytic activity and levels of ChTRase as well as numbers of positive cells in bronchial biopsies in patients with COPD who were either former or current smokers. In addition, while correlating strongly with most of the respiratory alterations seen in this disease, including airflow obstruction and transfer factor of the lung for carbon monoxide, which reflects impaired diffusion lung capacity seen in emphysema, these parameters were unrelated to smoking history. These results suggest that elevated ChTRase levels in the airways do not simply result from an ongoing inflammatory process secondary to cigarette smoking, but rather are characteristic of COPD and indeed may be a hallmark of disease activity.

Previous studies established that the expression of ChTRase in phagocytic cells is differentially regulated by a number of pro-inflammatory cytokines that have been suggested to be involved in the pathogenesis of COPD, including granulocyte-macrophage colony-stimulating factor, IL-1 $\beta$, TNF- $\alpha$, and interferon- $\gamma^{3,27,28}$ We found that amounts of IL- $1 \beta$, TNF- $\alpha$ and of its type II soluble receptor, TNF-RII, were elevated in BAL from patients with COPD, as compared to smokers without COPD, or to never-smokers. Chitinolytic activity and levels of ChTRase significantly correlated with the concentrations of $\mathrm{IL}-1 \beta$, TNF- $\alpha$, and TNF-RII in BAL supporting the hypothesis of a mutual regulation in the production of these mediators in the airways of patients with COPD. Whether other factors that are overexpressed during COPD may participate in the induction of ChTRase in alveolar macrophages and whether they also modulate the expression of this enzyme in bronchiolar epithelial cells is an area for further investigation.

Although alveolar macrophages were the main sources of ChTRase, we also detected this chitinase in polynuclear neutrophils, particularly in proximal airways. These findings extend previous observations showing that phagocytes synthesize ChTRase, both in the circulation and in normal and diseased tissues. ${ }^{8,29,30}$ The number of macrophages and, to a lesser extent, of neutrophils, is higher in $\mathrm{COPD}^{31,32}$ and this may account, at least in part, for the increase in BAL levels of ChTRase observed in smokers with COPD. However, we also found that the proportion of alveolar macrophages containing ChTRase was substantially increased in smokers with COPD, when compared to smokers without COPD or to never-smokers, with approximately $80 \%$ of cells expressing this protein. In ad- 
dition, ChTRase was readily detectable in the bronchiolar epithelium from smokers with COPD, but not in smokers without COPD, nor in never-smokers. These observations suggest that both an increased rate of alveolar macrophages producing ChTRase, as well as newly acquired ability of bronchiolar epithelial cells to synthesize this chitinase may contribute to the elevation of the enzyme in BAL from smokers with COPD.

Alveolar macrophages from smokers and, to a greater degree, from patients with COPD exhibited increased baseline mRNA and secretion of ChTRase, as compared to never-smokers. These results extend previous reports of amplified spontaneous production of the inflammatory chemokine, IL-8, by alveolar macrophages from smokers and from COPD patients. ${ }^{3,33}$ However, we also found that TNF- $\alpha$ induced the production of significant amounts of ChTRase exclusively from alveolar macrophages from smokers with COPD, suggesting that the diseased airway environment 'primes' these cells to generate elevated amounts of this chitinase. These observations are somewhat reminiscent of previous findings showing prominent induction of ChTRase in macrophages in vessel atherosclerotic plaques ${ }^{8}$ and in Gaucher disease, an inherited deficiency in a lysosomal hydrolase that leads to the formation of lipid-laden macrophages that accumulate in the vessel wall. ${ }^{34}$

Exposure of alveolar macrophages to ChTRase also resulted in the production of IL-8 and MCP-1, two chemokines that sustain tissue inflammation and fibrosis, and of MMP-9, which is primarily involved in matrix degradation and in the accompanying alveolar destruction seen in emphysema. ${ }^{3,4}$ The strong correlation that we found between BAL levels of ChTRase and IL-8 in smokers with and without COPD further supports this causal relationship. The effects of $10 \mu \mathrm{g} / \mathrm{ml}$ of ChTRase were similar to those induced by TNF- $\alpha$. These apparent biologically active high concentrations of ChTRase are however within the range of those found in the serum of subjects with chronic inflammatory diseases that are characterized by aberrant macrophage activation. ${ }^{35}$

Finally, we determined whether in vivo ChTRase overexpression in the normal lung would result in inflammatory alterations. We found that mice that had received an adenoviral vector encoding murine ChTRase had higher numbers of alveolar macrophages and showed elevated synthesis of the murine homologue of IL-8, KC, and of MCP-1. These observations suggest that ChTRase is sufficient to promote lung inflammation in normal mice, most likely by activating macrophages and airway epithelial cells, ie, the main sources of IL-8 and MCP-1 in the airways during COPD. ${ }^{36}$

The identification of the mechanisms involved in airway inflammation and remodeling that lead to chronic limitation of airflow is essential for a better understanding of the pathogenesis of COPD and for the development of novel treatments aimed at limiting the onset and progression of the disease. ${ }^{1,4,37}$ Our current observations identify ChTRase as a potentially important and new driver of tissue pathological alterations seen in COPD. Strategies aimed at specifically neutralizing chitinolytic activity or at limit- ing ChTRase synthesis may be of therapeutic value to improve COPD management.

\section{Acknowledgments}

We thank the subjects who participated in the study and Lori Clarke for construction of AdV.

\section{References}

1. Barnes PJ: Chronic obstructive pulmonary disease. N Engl J Med 2000, 343:269-280

2. Hogg JC: Pathophysiology of airflow limitation in chronic obstructive pulmonary disease. Lancet 2004, 364:709-721

3. Barnes PJ: Mediators of chronic obstructive pulmonary disease. Pharmacol Rev 2004, 56:515-548

4. MacNee W: Pathogenesis of chronic obstructive pulmonary disease. Proc Am Thorac Soc 2005, 2:258-266

5. Barnes PJ: Alveolar macrophages as orchestrators of COPD. COPD 2004, 1:59-70

6. Bleau G, Massicotte F, Merlen Y, Boisvert C: Mammalian chitinaselike proteins. EXS 1999, 87:211-221

7. Gooday GW: Aggressive and defensive roles for chitinases. EXS 1999, 87:158-169

8. Herrera-Estrella A, Cher I: Chitinases in biological control. EXS 1999 $87: 171-184$

9. Boot RG, van Achterberg AE, van Aken BE, Renkema GH, Jacobs MJHM, Aerts JM, de Vries CJ: Strong induction of members of the chitinase family of proteins in atherosclerosis: chitotriosidase and human cartilage gp-39 expressed in lesion macrophages. Arterioscler Thromb Vasc Biol 1999, 19:687-694

10. Artieda M, Cenarro A, Ganan A, Jerico I, Gonzalvo C, Casado JM, Vitoria I, Puzo J, Pocoví M, Civeira F: Serum chitotriosidase activity is increased in subjects with atherosclerosis disease. Arterioscler Thromb Vasc Biol 2003, 23:1645-1652

11. Zhu Z, Zheng T, Homer RJ, Kim Y-K, Chen NY, Cohn L, Hamid Q, Elias JA: Acidic mammalian chitinase in asthmatic Th2 inflammation and IL-13 pathway activation. Science 2004, 304:1678-1682

12. Rabe KF, Hurd S, Anzueto A, Barnes PJ, Buist SA, Calverley P, Fukuchi $Y$, Jenkins C, Rodriguez-Roisin R, van Weel C, Zielinski J: Global strategy for the diagnosis. management, and prevention of chronic obstructive pulmonary disease GOLD executive summary. Am J Respir Crit Care Med 2007, 176:532-555

13. Global Strategy for Asthma Management and Prevention, Global Initiative for Asthma (GINA), 2008. Available from http://www.ginasthma.org

14. Létuvé S, Kozhich A, Arouche N, Grandsaigne M, Reed J, Dombret MC, Kiener PA, Aubier M, Coyle AJ, Pretolani M: YKL-40 is elevated in patients with chronic obstructive pulmonary disease and activates alveolar macrophages. J Immunol 2008, 181:5167-5173

15. Benayoun L, Druilhe A, Dombret MC, Aubier M, Pretolani M: Airway structural alterations selectively associated with severe asthma. Am J Respir Crit Care Med 2003, 167:1360-1368

16. Chupp GL, Lee CG, Jarjour N, Shim YM, Holm CT, He S, Dziura JD, Reed J, Coyle AJ, Kiener P, Cullen M, Grandsaigne M, Dombret MC, Aubier M, Pretolani M, Elias JA: A chitinase-like protein in the lung and circulation of patients with severe asthma. N Engl J Med 2007, 357:2016-2027

17. Pégorier S, Wagner LA, Gleich GJ, Pretolani M: Eosinophil-derived cationic proteins activate the synthesis of remodeling factors by airway epithelial cells. J Immunol 2006, 177:4861-4869

18. Vignali DA: Multiplexed particle-based flow cytometry assays. J Immunol Methods 2000, 243:243-255

19. Luo J, Deng ZL, Luo X, Tang N, Song WX, Chen J, Sharff KA, Luu HH, Haydon RC, Kinzler KW, Vogelstein B, He TC: A protocol for rapid generation of recombinant adenoviruses using the AdEasy system. Nat Protoc 2007, 2:1236-1247

20. Brockhaus M, Schoenfeld HJ, Schlaeger EJ, Hunziker W, Lesslauer W, Loetscher $\mathrm{H}$ : Identification of two types of tumor necrosis factor receptors on human cell lines by monoclonal antibodies. Proc Natl Acad Sci USA 1990, 87:3127-3131 
21. Boot RG, Blommaart EF, Swart E, Ghauharali-van der Vlugt K, Bijl $\mathrm{N}$, Moe C, Place A, Aerts JM: Identification of a novel acidic mammalian chitinase distinct from chitotriosidase. J Biol Chem 2001 276:6770-6778

22. Seibold MA, Donnelly S, Solon M, Innes A, Woodruff PG, Boot RG, Burchard EG, Fahy JV: Chitotriosidase is the primary active chitinase in the human lung and is modulated by genotype and smoking habit. J Allergy Clin Immunol 2008, 122:944-950

23. Boot RG, Renkema GH, Verhoek M, Strijland A, Bliek J, de Meulemeester TM, Mannens MM, Aerts JM: The human chitotriosidase gene. Nature of inherited enzyme deficiency. J Biol Chem 1998, 273:25680-25685

24. Bousquet J, Jeffery P, Busse WW, Johnson M, Vignola AM: Asthma. From bronchoconstriction to airways inflammation and remodeling Am J Respir Crit Care Med 161:1720-1745, 2000

25. Bierbaum S, Nickel R, Koch A, Lau S, Deichmann KA, Wahn U, Superti-Furga A, Heinzmann A: Polymorphisms and haplotypes of acid mammalian chitinase are associated with bronchial asthma. Am J Respir Crit Care Med 2005, 172:1505-1509

26. Bierbaum S, Superti-Furga A, Heinzmann A: Genetic polymorphisms of chitotriosidase in Caucasian children with bronchial asthma. Int J Immunogenet 2006, 33:201-204

27. van Eijk M, van Roomen $C P$, Renkema GH, Bussink AP, Andrews L, Blommaart EF, Sugar A, Verhoeven AJ, Boot RG, Aerts JM: Characterization of human phagocyte-derived chitotriosidase, a component of innate immunity. Int Immunol 2005, 17:1505-1512

28. Malaguarnera L, Musumeci M, Di Rosa M, Scuto A, Musumeci S: Interferon-gamma, tumor necrosis factor-alpha, and lipopolysaccharide promote chitotriosidase gene expression in human macrophages. J Clin Lab Anal 2005, 19:128-132

29. Renkema GH, Boot RG, Au FL, Donker-Koopman WE, Strijland A,
Muijsers AO, Hrebicek M, Aerts JM: Chitotriosidase, a chitinase, and the 39-kDa human cartilage glycoprotein, a chitin-binding lectin, are homologues of family 18 glycosyl hydrolases secreted by human macrophages. Eur J Biochem 1998, 251:504-509

30. Bouzas L, Carlos Guinarte J, Carlos Tutor J: Chitotriosidase activity in plasma and mononuclear and polymorphonuclear leukocyte populations. J Clin Lab Anal 2003, 17:271-275

31. Retamales I, Elliott WM, Meshi B, Coxson HO, Pare PD, Sciurba FC Rogers RM, Hayashi S, Hogg JC: Amplification of inflammation in emphysema and its association with latent adenoviral infection. Am J Respir Crit Care Med 2001, 164:469-473

32. Di Stefano A, Capelli A, Lusuardi M, Balbo P, Vecchio C, Maestrelli P, Mapp CE, Fabbri LM, Donner CF, Saetta M: Severity of airflow limitation is associated with severity of airway inflammation in smokers. Am J Respir Crit Care Med 1998, 158:1277-1285

33. Culpitt SV, Rogers DF, Shah P, De Matos C, Russell RE, Donnelly LE, Barnes PJ: Impaired inhibition by dexamethasone of cytokine release by alveolar macrophages from patients with chronic obstructive pulmonary disease. Am J Respir Crit Care Med 2003, 167:24-31

34. Hollak CE, van Weely S, van Oers MH, Aerts JM: Marked elevation of plasma chitotriosidase activity. A novel hallmark of Gaucher disease J Clin Invest 1994, 93:1288-1292

35. Vissers JP, Langridge JI, Aerts JM: Analysis and quantification of diagnostic serum markers and protein signatures for Gaucher disease. Mol Cell Proteomics 2007, 6:755-766

36. de Boer WI, Sont JK, van Schadewijk A, Stolk J, van Krieken JH, Hiemstra PS: Monocyte chemoattractant protein 1, interleukin 8, and chronic airways inflammation in COPD. J Pathol 2000, 190:619-626

37. Barnes PJ: Chronic obstructive pulmonary disease: a growing but neglected global epidemic. PLoS Med 2007, 4:e112 